\title{
Analisis Pengaruh Kualitas SDM Dan Efektifitas Penggunaan SIDUPA Pada Kinerja Pegawai Di Kabupaten Badung
}

\author{
$\underline{\text { I Putu Indra Yohana }}$ \\ Sistem Informasi Akuntansi, STMIK Primakara, Denpasar \\ Jl. Tukad Badung, no. 135, Renon, Denpasar, 03618956084 \\ E-mail: indrayohana10@gmail.com
}

\begin{abstract}
Badung Regency now using technology to help their works including in compiling potential tax. The technology that used by them is called Sistem Informasi Pengaduan Potensi Pajak (SIDUPA). This research is analysing the effect of human resources quality and the operation effectivity of SIDUPA in the performances of Badung Regency government employees. Moreover, the formulation of problem in this analytical research are "Do the human resource quality effecting the performances of the employees?" and "Do effectivity of using SIDUPA affecting performances of the government employees in Badung Regency?". Therefore, this research aims and objective are to prove that human resource quality and effectivity of SIDUPA affecting to the performances of government employees in Badung Regency using empiric data. This is a quantitative research susing SSPS as the measuring instruments to gather the data and compile it. The model that will be used to analyse and test the hypothesis in this research is Multiple Linear Regression Model. For the conclusion, based on the data that have been analysed, the human resource quality and the effectivity of using SIDUPA resulting in a significant and positive partial outcome towards government employees in Badung Regency.
\end{abstract}

Keywords:, Human Resource Quality, Employees Performance, Quantitative, Multiple Linear Regression.

\begin{abstract}
Abstrak
Kabupaten Badung merupakan salah satu kabupaten yang menggunakan teknologi guna memudahkan pekerjaannya, teknologi tersebut adalah Sistem Informasi Pengaduan Potensi Pajak (SIDUPA). Penelitian tentang "Analisis Pengaruh Kualitas SDM Dan Efektifitas Penggunaan SIDUPA Pada Kinerja Pegawai Di Kabupaten Badung" memiliki rumusan masalah Apakah kualitas sumber daya manusia berpengaruh kepada kinerja pegawai dan apakah efektifitas penggunaan SIDUPA (Sistem Informasi Pengaduan Potensi Pajak) berpengaruh pada kinerja pegawai di Pemerintah Kabupaten Badung. Tujuan penelitian ini adalah memberikan bukti empiris bahwa kualitas SDM dan efektifitas SIDUPA berpengaruh terhadap kinerja peggawai di Kabupaten Badung. Penelitian ini menggunakan metode penelitian kuantitatif dengan menggunakan alat ukur perhitungan berupa software SPSS. Model yang digunakan untuk melakukan analisis data dan pengujian hipotesis dalam penelitian ini adalah model analisis regresi linier berganda. Berdasarkan analisa data yang dilakukan, diperoleh kesimpulan bahwa, Kualitas sumber daya manusia dan efektivitas penggunaan SIDUPA berpengaruh positif dan signifikan secara parsial terhadap kinerja pegawai di Kabupaten Badung.
\end{abstract}

Kata kunci: Kualitas Sumber Daya Manusia, Kinerja Pegawai, analisis regresi linier berganda

(C) 2019 Jurnal Ilmiah MEDIA SISFO.

\section{Pendahuluan}

Pada zaman modern ini, setiap perusahaan menuntut diri agar bisa mengembangkan diri dan ikut dalam persaingan global. Tidak hanya perusahaan yang menuntut diri agar bisa mengikuti perkembangan zaman instansi pemerintahpun juga ikut melakukan perubahan seiring dengan berkembangnya teknologi. Salah satu instansi pemerintah yang mengikuti perkembangan zaman dan memanfatkan teknologi dalam melakukan aktifitasnya adalah Dinas Pendapatan Daerah/Pasedahaan Agung Kabupaten Badung.

Dinas Pendapatan Daerah/Pasedahan Agung selaku SKPD pengelola pendapatan, memiliki tujuan pokok yakni Peningkatan Pendapatan Asli Daerah (PAD) Kabupaten Badung. Peningkatan PAD merupakan 
syarat utama dalam mewujudkan pengelolaan tata kelola pemerintahan yang lebih baik, karena PAD merupakan cerminan dari kemandirian daerah dalam melaksanakan otonomi daerah. Untuk meningkatkan PAD tentunya kinerja pegawai sangatlah berpengaruh didalamnya.

Kinerja pegawai didefinisikan sebagai kemampuan pegawai dalam melakukan sesuatu keahlian tertentu. Kinerja pegawai sangatlah perlu, sebab dengan kinerja ini akan diketahui seberapa jauh kemampuan pegawai dalam melaksanakan tugas yang dibebankan kepadanya [1]. Berkaitan dengan kinerja pegawai untuk meningkatkan PAD tentunya dibutuhkan kualitas sumberdaya yang mumpuni beserta sistem yang baik oleh karena itu maka perumusan masalah dalam penelitian ini adalah sebagai berikut:

a. Apakah kualitas sumber daya manusia berpengaruh kepada kinerja pegawai di Pemerintah Kabupaten Badung?

b. Apakah efektifitas penggunaan Sistem Informasi Pengaduan Pajak (SIDUPA), berpengaruh pada kinerja pegawai di Pemerintah Kabupaten Badung?

\section{Tinjauan Pustaka}

\subsection{Landasan Teori}

Manajemen sumber daya manusia (MSDM) dapat diartikan sebagai ilmu dan seni yang mengatur hubungan dan peranan tenaga kerja agar efektif dan efisien dalam penggunaan kemampuan manusia agar dapat mencapai tujuan di setiap perusahaan [2]. Efektifitas adalah Kemampuan seseorang atau suatu organisasi dalam mencapai apa yang diharapkan dengan dilihat dari suatu kurun kinerja dari seseorang atau suatu organisasi tersebut [3]

Definisi Sistem Akuntansi Pemerintahan menurut PP No. 24 Tahun 2005 tentang Standar Akuntasi Pemerintahan: Sistem akuntansi pemerintahan adalah serangkaian prosedur manual maupun yang terkomputerisasi mulai dari pengumpulan data, pencatatan, pengikhtisaran dan pelaporan posisi keuangan dan operasi pemerintah [4]. Akuntansi keuangan daerah dapat di definisikan sebagai Suatu proses identifikasi, pengukuran, dan pelaporan transaksi ekonomi (keuangan) dari suatu daerah (Provinsi, kabupaten, Kota) yang dijadikan sebagai informasi dalam pengambilan keputusan ekonomi oleh pihakpihak yang memerlukan [5].

Berdasarkan Permendagri No. 13 Tahun 2006 yang terdapat pada pasal 232 menyatakan bahwa Sistem Akuntansi Keuangan Daerah merupakan serangkaian prosedur mulai dari proses pengumpulan data, pencatatan, pengikhtisaran, sampai dengan pelaporan keuangan dalam rangka pertanggungjawaban pelaksanaan APBD yang dapat dilakukan secara manual atau menggunakan komputer [6].

Suatu sistem informasi (SI) dapat didefinisikan secara teknis sebagai suatu rangkaian yag komponenkomponennya saing terkait yang mengumpulkan (dan mengambil kembali), memproses, menyimpan, dan mendistribusikan informasi untuk mendukung pengambilan keputusan dan mengendalikan perusahaan [7].

Setiap pegawai dalam organisasi dituntut untuk memberikan kontribusi positif melalui kinerja yang baik, mengingat kinerja organisasi tergantung pada kinerja pegawainya. Adapun pendapat para ahli mengenai pengertian kinerja, sebagai berikut:

1. Kinerja adalah hasil kerja secara kualitas dan kuantitas yang dicapai oleh seorang pegawai dalam melaksanakan tugasnya sesuai dengan tanggung jawab yang diberikan kepadanya [8].

2. Kinerja pegawai didefinisikan sebagai kemampuan pegawai dalam melakukan sesuatu keahlian tertentu. Kinerja pegawai sangatlah perlu, sebab dengan kinerja ini akan diketahui seberapa jauh kemampuan pegawai dalam melaksanakan tugas yang dibebankan kepadanya. Untuk itu diperlukan penentuan kriteria yang jelas dan terukur serta ditetapkan secara bersama-sama yang dijadikan sebagai acuan [9].

\section{Metodologi}

Metode yang digunakan dalam melakukan penelitian ini adalah dengan menggunakan metode penelitian kuantitatif dan didukung menggunakan alat ukur perhitungan yaitu berupa software SPSS. Metode penelitian kuantitatif dapat diartikan sebagai metode penelitian yang berlandaskan pada filsafat 
positivisme, digunakan untuk meneliti pada populasi atau sampel tertentu, teknik pengambilan sampel pada umumnya dilakukan secara acak, pengumpulan data menggunakan instrumen penelitian, analisis data bersifat kuantitatif/statistik dengan tujuan untuk menguji hipotesis yang telah ditetapkan [10].

\subsection{Metode Pengumpulan Data}

Kegiatan pengumpulan data dilakukan dengan metode :

1. Kuesioner

Kuesioner adalah sejumlah pertanyaan tertulis yang digunakan oleh peneliti untuk mendapatkan informasi dari responden.

2. Wawancara

Wawancara adalah percakapan yang diamana ada maksud tertentu untuk mendapatkan informasi yang dilakukan dua pihak atau lebih.

3. Penelitian Kepustakaan (Library Research)

Peneliti kepustakaan dilakukan dengan cara menganalisa fakta-fakta yang akan berupa pendapat, hasil kerja dan karya-karya para ahli yang terdapat dalam buku, jurnal, majalah dan dokumen lainnya serta studi internet.

\subsection{Metode Analisis Data}

Untuk melakukan analisis data pada penelitian ini penulis menggunakan metode regresi linier berganda. Dimana regresi linier berganda merupakan lanjutan dari regresi linier sederhana, regresi linier sederhana hanya menyediakan satu variabel independen $(\mathrm{x})$ dan satu variabel dependen $(\mathrm{y})$ sedangkan regresi linier berganda dapat menggunakan lebih dari satu variabel independen $(\mathrm{x})$. Dikarenakan variabel independen (x) dalam penelitian ini lebih dari satu maka peneliti menggunakan metode regresi linier berganda.

\subsection{Jenis Data}

Dalam penelitian ini penulis lebih berfokus kepada data kuantitatif dimana unit yang akan dianalisis adalah karyawan yang ada di badan pemerintahan kabupaten Badung. Data akan dikumpulkan melalui penyebaran kuesioner dimana kuesioner akan menyangkut informasi mengenai pengaruh kualitas sumber daya manusia dan efektifitas penggunaan sistem informasi pengaduan potensi pajak di kabupaten badung yang dinyatakan dalam angka-angka meliputi skor nilai dari jawaban kuesioner yang diisi oleh responden.

\subsection{Sumber Data}

Sumber data yang digunakan dalam penelitian ini yaitu :

1. Data Primer, didapatkan melalui observasi, wawancara dan penyebaran kuisioner secara langsung dengan beberapa pihak yang terkait dengan sistem dan sumber daya manusia yang ada di Kabupaten Badung.

2. Data Sekunder, dalam penelitian ini diperoleh dari informasi yang dihasilkan dari penelitian sebelumnya yang berhubungan dengan penelitian yang dilakukan oleh penulis, selain itu data juga didapatkan dari hasil pencarian peneliti yang bersumber dari internal maupun eksternal instansi terkait. Selain itu peneliti juga mendapatkan informasi melalui peninjauan pustaka yang dilakukan.

\subsection{Tempat \& Waktu Penelitian}

Objek penelitian ini adalah Badan Pendapatan Daerah/Pasedahan Agung dan kecamatan yang ada di seputaran wilayah Kabupaten Badung. Penelitian ini dilakukan dari bulan desember 2017 - Juli 2018.

\subsection{Variabel Penelitian}

Variabel yang digunakan dalam penelitian ini adalah :

1. Variabel Terikat/Dependen

Dalam penelitian ini yang menjadi variabel terikat adalah adalah kinerja pegawai. 
2. Variabel Bebas/Independen

Pada penelitian ini yang menjadi variabel bebas adalah: kualitas sumber daya manusia dan efektifitas sistem informasi pengaduan potensi pajak yang ada di Kabupaten Badung.

\subsection{Responden Penelitian}

Responden dalam penelitian ini adalah yaitu :

1. Bagian Teknologi Informasi yang bersentuhan langsung dengan sistem di Bapenda.

2. Bagian Teknologi Informasi yang bersentuhan langsung dengan sistem informasi pengaduan potensi pajak di masing-masing kecamatan di Kabupaten Badung.

\subsection{Operasional Variabel}

Definisi operasional dan pengukuran variabel disajikan pada Tabel dibawah ini

Tabel 1 Definisi Operasional dan Pengukuran Variabel

Variabel

Definisi Operasional

\begin{tabular}{ll}
\hline Kualitas Sumber & Kemampuan baik dalam tingkatan individu, organisasi/kelembagaan, \\
Daya Manusia & maupun sistem untuk melaksanakan fungsi-fungsi atau kewenangannya \\
& untuk memaksimalkan potensi pajak yang ada di Kabupaten Badung.
\end{tabular}

Sistem Informasi

Tingkat integrasi sistem informasi pengaduan potensi pajak pada efesiensi

Pengaduan kinerja pegawai di Kabupaten Badung

Potensi Pajak

Kinerja Pegawai

Tingkat prestasi pegawai dalam memaksimalkan pemantauan potensi pajak yang ada di Kabupaten Badung

\subsection{Rancangan Penelitian}

Rancangan Penelitian ini digambarkan seperti nampak pada Gambar 1 sebagai berikut:

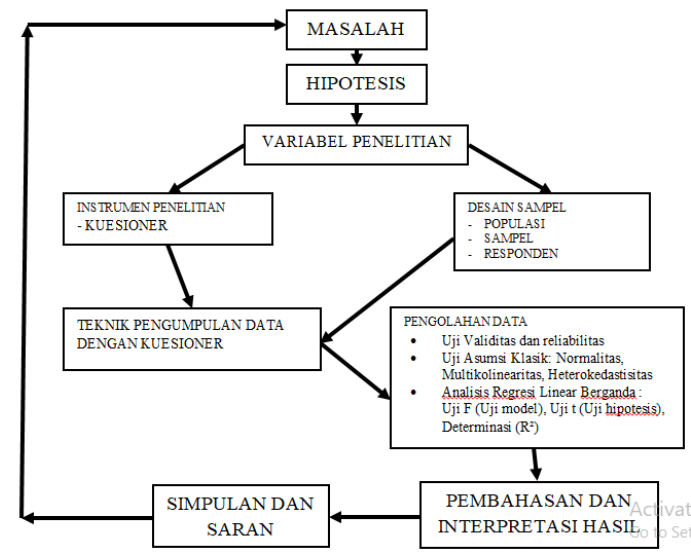

\subsection{Desain Penelitian}

Gambar 1. Rancangan Penelitian

Untuk memberikan gambaran mengenai variabel dan indikator yang ditetapkan sebagai proksi dari masing-masing variabel penting untuk dirumuskan desain penelitian. Desain penelitian ini dapat digambarkan seperti pada gambar dibawah ini: 


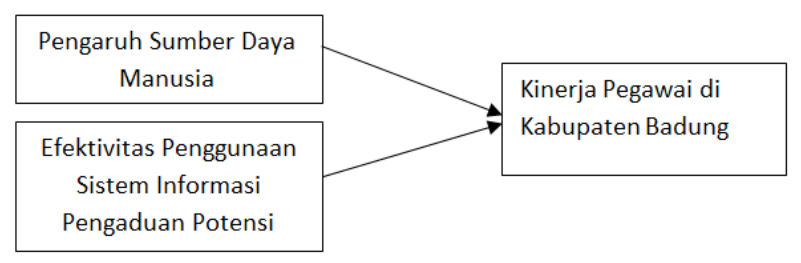

Gambar 2. Desain Penelitian

\subsection{Uji Instrumen Penelitian}

\subsubsection{Uji Validitas dan Reliabilitas}

Instrumen penelitian yang baik adalah instrumen penelitian yang reliabel dan valid. Untuk mengetahui validitas data maka perlu dilakukan uji validitas. Uji validitas merupakan uji instumen data untuk mengetahui seberapa cermat suatu item dalam mengukur apa yang ingin diukur [11]. Dasar pengambilan keputusan pada uji validitas dalam penelitian ini adalah instrumen dikatakan valid bila koefisien korelasinya lebih dari 0,30 . Uji reliabilitas dan validitas dilakukan dengan bantuan program SPSS. Selanjutnya untuk uji reliabilitas terhadap instrumen dilakukan dengan koefisien cronbach's alpha, jika koefisien cronbach's alpha memiliki lebih dari 0,60 maka instrumen yang digunakan dikatakan reliable.

\subsubsection{Pengujian Asumsi Klasik}

Uji ini dimaksudkan untuk mengetahui ada tidaknya pelanggaran asumsi klasik dalam model regresi linear berganda. Penyimpangan terhadap asumsi tersebut akan menghasilkan estimasi yang tidak sahih. Uji yang akan dilakukan adalah uji Normalitas, Heteroskedastisitas dan uji Multikolinearitas.

\section{Uji Normalitas}

Uji normalitas bertujuan untuk mengetahui normal atau tidaknya suatu distribusi data [12]. Uji normalitas digunakan untuk memperlihatkan bahwa data berdistribusi normal, mengetahui apakah variabel-variabel yang di gunakan memenuhi asumsi normalisasi. Dalam penelitian ini, untuk menguji apakah distribusi data normal atau tidak dapat dilakukan :

a. Melihat normal probability plot dengan cara membandingkan distribusi kumulatif dari data sesungguhnya dengan distribusi komulatif dari distribusi normal.

b. Dengan menggunakan uji Kolmogorov-Sminarnov yaitu membandingkan distribusi kumulatif relatif hasil observasi dengan distribusi komulatif relatif teoritisnya. Data populasi dikatakan berdistribusi normal jika koefisien Asymp Sig (2-tailed) lebih besar dari $\alpha=0,05$.

\section{Uji Heteroskedastisitas}

Sarjono dan Julianita mengartikan bahwa uji heteroskedastisitas menunjukkan varian variabel tidak sama untuk semua pengamatan atau observasi, jika varian dari residual satu pengamatan ke pengamatan yang lain tetap maka disebut homoskedastisitas [12]. Model regresi yang baik adalah terjadi homoskedastisitas atau dengan perkataan lain tidak terjadi homoskedastisitas. Heteroskedastisitas menunjukkan tidak konstannya varians dari variabel pengganggu (disturbance). Kebanyakan data cross-section mengalami situasi ini, karena data ini mewakili berbagai ukuran (kecil, sedang dan besar). Pengujian heteroskedastisitas dilakukan dengan uji Glejser yakni dengan cara meregresi nilai absolut residual dari model yang diestimasi terhadap variabel independen. Kriterianya apabila output koefisien parameter untuk variabel bebas tidak ada yang signifikan secara statistik, maka disimpulkan bahwa model regresi tidak terdapat heteroskedastisitas.

\section{Uji Multikolinearitas}

Uji multikolinearitas merupakan suatu situasi dimana beberapa atau semua variabel bebas berkorelasi kuat. Pengujian multikolinearitas dapat dilakukan dengan cara melakukan regresi antar variabel independennya untuk melihat nilai tolerance atau variance inflation factor (VIF) dari masing-masing variabel independen. Apabila nilai tolerance kurang dari 0,10 atau nilai VIF lebih besar dari 10, maka ada indikasi terjadi multikolinearitas yang serius. Sebaliknya apabila nilai tolerance lebih dari 0,10 atau nilai VIF kurang dari 10, maka tidak terdapat gejala multikolinearitas. Adapun rumus mencari VIF adalah : 


$$
\mathrm{VIF}=1 /(1-\mathrm{R} 2)[13] .
$$

\subsubsection{Analisis Data}

Model yang digunakan untuk melakukan analisis data dan pengujian hipotesis dalam penelitian ini adalah model analisis regresi linier berganda. Menurut Priyatno analisis regresi linier berganda digunakan untuk mengetahui pengaruh atau hubungan secara linier antara dua variabel atau lebih variabel independen dengan satu variabel dependen [11]. Rumus umum regresi berganda. Secara matematis bentuk persamaan regresi linier berganda adalah sebagai berikut:

$$
\mathrm{Y}=\alpha+\beta 1 \mathrm{X} 1+\beta 2 \mathrm{X} 2+\beta 3 \mathrm{X} 3
$$

Keterangan:

$$
\begin{array}{ll}
\mathrm{Y} & : \text { Pengaruh Terhadap Pendapatan Asli Daerah } \\
\alpha & : \text { Konstanta } \\
\beta 1, \beta 2, \beta 3, & : \text { Koefisien regresi } \\
\mathrm{X} 1 & : \text { Kualitas Sumber Daya Manusia } \\
\mathrm{X} 2 & : \text { Pemanfaatan Sistem Informasi Pengaduan Potensi Pajak }
\end{array}
$$

Uji hipotesis dengan analisis regresi linier berganda dapat diukur dari Uji Statistik F, Uji Statistik t dan koefisien Determinasi $\left(\mathrm{R}^{2}\right)$ sebagai berikut:

1. Uji Statistik F (Uji Simultan)

Uji kelayakan model (model fit) dilakukan dengan uji F (F-test). Uji F, yaitu pengujian terhadap variabel independen secara bersama (simultan) yang ditujukan untuk mengetahui apakah semua variabel independen secara bersama-sama dapat berpengaruh terhadap variabel dependen [14]. Uji ini dimaksudkan untuk mengetahui kedua variabel independen mempengaruhi kinerja pegawai di Pemerintah Daerah kabupaten Badung sebagai variabel terikat. Apabila hasil uji $\mathrm{F}$ adalah signifikan atau P-value $<0,05$ maka hubungan variabel-variabel independen adalah signifikan mempengaruhi kinerjs pegswsi di kabupaten Badung dan model regresi yang digunakan layak uji.

2. Uji Statistik t (Uji Parsial)

Pengujian ini dilakukan untuk mengetahui signifikan tidaknya pengaruh masing-masing variabel bebas secara individual pada variabel terikat. Untuk menguji hipotesis yang diajukan apakah diterima atau ditolak dengan cara membandingkan antara $\mathrm{t}$ hitung dengan $\mathrm{t}$ tabel pada taraf signifikasi $0,05(5 \%)$. Apabila signifikansinya di bawah atau sama dengan 0,05 maka $\mathrm{H} 1$ diterima dan Ho ditolak. Jika nilai thitung lebih besar dari $t$ tabel, maka Ho ditolak, dan jika nilai t hitung lebih kecil dari t tabel, maka Ho diterima.

\section{Determinasi $\left(R^{2}\right)$}

Analisis ini digunakan untuk mengetahui seberapa besar variasi kualitas sumber daya manusia dan efektifitas sistem informasi pengaduan potensi pajak berpengaruh pada kinerja pegawai di kabupaten Badung. Pengolahan data akan dilakukan dengan menggunakan bantuan komputer dengan piranti lunak SPSS.

\section{Hasil dan Pembahasan}

4.1 Deskripsi Responden

Data hasil penelitian ini diperoleh dari 7 kecamatan ditambah 1 Badan Pendapatan Daerah di Lingkungan Pemerintah Kabupaten Badung. Selanjutnya karakteristik responden akan dianalisis dari 3 hal, yaitu umur, jenis kelamin dan tingkat pendidikan. Untuk usia responden disini menggambarkan tingkat kedewasaan responden dan berpengaruh terhadap partisipasi dalam komunikasi dan pengambilan keputusan. Berdasarkan gambar 3 dapat dilihat responden yang memiliki umur 20-30 tahun 3 responden (7\%). Responden yang memiliki umur 31-40 tahun 10 responden (24\%). Responden yang memiliki umur 41-50 tahun terbanyak yaitu 10 responden (24\%). Responden yang memiliki umur diatas 50 tahun 19 responden $(45 \%)$. Berdasarkan hasil tersebut maka didapat bahwa sebesar 55\% responden berada pada 
usia yang kognitif untuk mengambil keputusan yaitu pada rentan usia 20-50 tahun dan dan berpengaruh positif dalam pengambilan keputusan.

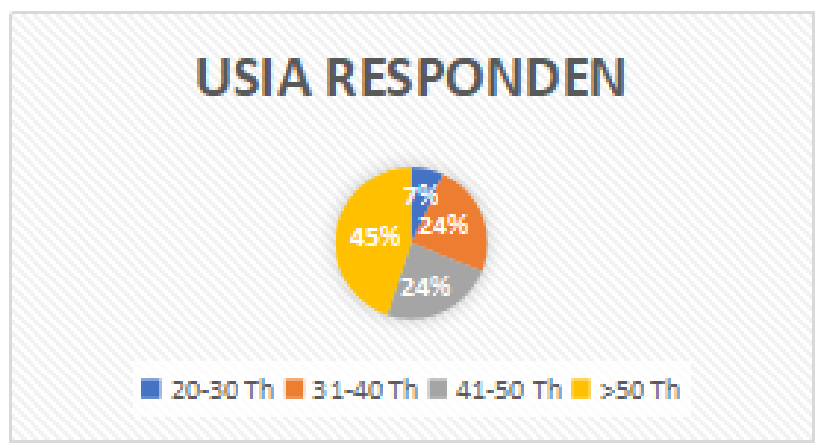

Gambar 3 Usia Responden

Selanjutnya untuk jenis kelamin responden disini digunakan untuk melihat pendistribusian kuisioner apakah terbagi sama rata atau tidak, selain itu juga untuk melihat kesenjangan antara responden laki-laki dan wanita dalam penggunaan sistem informasi potensi pengaduan pajak. Tetapi karena yang mengisi kuisioner diwajibkan untuk bersentuhan secara langsung dengan sistem yang penulis teliti maka didapat data sebagai berikut, yaitu hampir sebagian besar yang terlibat dalam sistem adalah laki-laki maka didapat data yaitu 26 responden $(62 \%)$ adalah laki-laki, sedangkan responden yang berjenis kelamin perempuan berjumlah 16 responden (38\%). Berdasarkan hasil diatas dapat diketahui bahwa untuk pekerjaan yang berurusan dengan sistem sebagian besar masih dipegang oleh laki-laki.

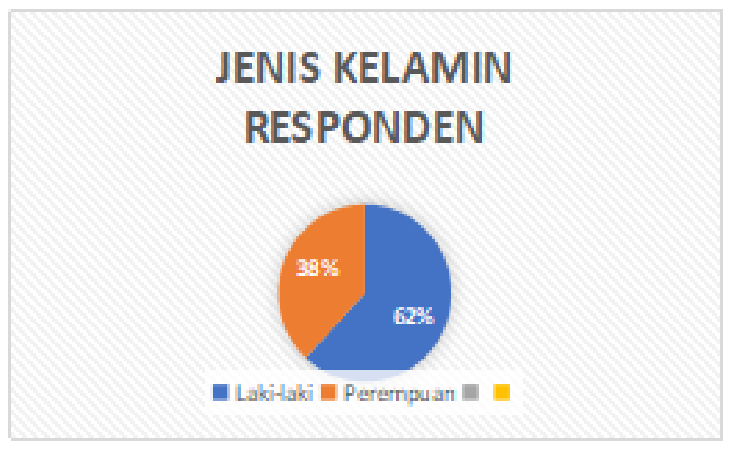

Gambar 4 Jenis Kelamin Responden

Terakhir adalah tingkat pendidikan responden. Tingkat pendidikan responden dapat digunakan sebagai indikator untuk mengetahui intelektualitas yang dimiliki. Tingkat pendidikan dapat digambarkan pola pikir yang dimiliki oleh responden. Pada gambar 5 dapat dilihat bahwa sebagian besar responden berpendidikan Sarjana (S1) dengan jumlah 23 responden (55\%), Magister (S2) sebanyak 10 responden (24\%), SMA dan sederajat berjumlah 8 responden (19\%), Doktor (S3) sebanyak 1 responden (2\%), tidak ada responden berpendidikan Diploma. Hal ini menunjukan bahwa sebagian besar pegawai yang berada dikecamatan Kabupaten Badung sudah mengenyam pendidikan yang cukup dalam bidang dan keahlian masing-masing yang nantinya akan mempermudah dalam melakukan pekerjaannya. 


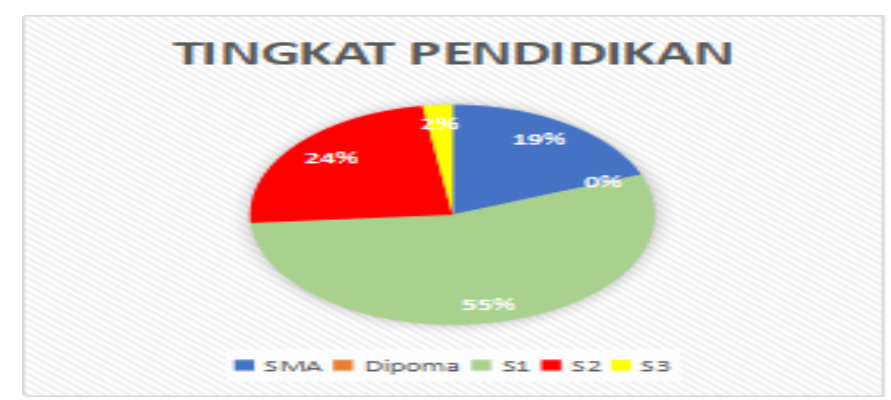

Gambar 5 Tingkat Pendidikan Responden

\subsection{Hasil Uji Validitas}

Uji validitas digunakan untuk mengukur sah atau valid tidaknya suatu kuesioner. Suatu kuesioner dikatakan valid jika:

a) Koefisien korelasi > 0,30 maka butir pernyataan tersebut valid

b) Koefisien korelasi $<0,30$ maka butir pernyataan tersebut tidak valid

Uji validitas pada penelitian ini dilakukan terhadap variabel kualitas sumber daya manusia. Hasil uji disajikan pada tabel 2.

Tabel 2 Hasil Uji Validitas Variabel Kualitas Sumber Daya Manusia

\begin{tabular}{cccc}
\hline No & Indikator & Koefisien Korelasi & Keterangan \\
\hline 1 & X1.1 & 0,987 & Valid \\
2 & X1.2 & 0,988 & Valid \\
3 & X1.3 & 0,725 & Valid \\
4 & X1.4 & 0,987 & Valid \\
5 & X1.5 & 0,988 & Valid \\
6 & X1.6 & 0,987 & Valid \\
7 & X1.7 & 0,988 & Valid \\
8 & X1.8 & 0,988 & Valid \\
\hline
\end{tabular}

Berdasarkan tabel 2 diketahui bahwa seluruh indikator dalam variabel kualitas sumber daya manusia memiliki koefisien korelasi yang lebih besar dari 0,30. Jadi dapat disimpulkan bahwa seluruh indikator telah memenuhi syarat validitas data.

Tabel 3 Hasil Uji Validitas Variabel Efektifitas Penggunaan Sistem Informasi Pengaduan Potensi Pajak

\begin{tabular}{cccc}
\hline No & Indikator & Koefisien Korelasi & Keterangan \\
\hline 1 & X2.1 & 0,598 & Valid \\
2 & X2.2 & 0,567 & Valid \\
3 & X2.3 & 0,706 & Valid \\
4 & X2.4 & 0,541 & Valid \\
5 & X2.5 & 0,699 & Valid \\
6 & X2.6 & 0,598 & Valid \\
7 & X2.7 & 0,567 & Valid \\
8 & X2.8 & 0,706 & Valid \\
9 & X2.9 & 0,541 & Valid \\
10 & X2.10 & 0,699 & Valid \\
\hline
\end{tabular}




\begin{tabular}{llll}
\hline 11 & X2.11 & 0,598 & Valid \\
12 & X2.12 & 0,567 & Valid \\
13 & X2.13 & 0,706 & Valid \\
14 & X2.14 & 0,541 & Valid \\
15 & X2.15 & 0,699 & Valid \\
16 & X2.16 & 0,598 & Valid \\
\hline
\end{tabular}

Berdasarkan tabel 3 diketahui bahwa seluruh indikator dalam variabel efektifitas penggunaan sistem informasi pengaduan potensi pajak memiliki koefisien korelasi yang lebih besar dari 0,30. Jadi dapat disimpulkan bahwa seluruh indikator telah memenuhi syarat validitas data.

Tabel 4 Hasil Uji Validitas Variabel Kinerja pegawai

\begin{tabular}{cccc}
\hline No & Indikator & Koefisien Korelasi & Keterangan \\
\hline 1 & Y.1 & 0,696 & Valid \\
2 & Y2 & 0,715 & Valid \\
3 & Y3 & 0,441 & Valid \\
4 & Y4 & 0,648 & Valid \\
5 & Y5 & 0,485 & Valid \\
6 & Y6 & 0,696 & Valid \\
7 & Y7 & 0,715 & Valid \\
8 & Y8 & 0,524 & Valid \\
9 & Y9 & 0,715 & Valid \\
10 & Y10 & 0,485 & Valid \\
11 & Y11 & 0,696 & Valid \\
12 & Y12 & 0,715 & Valid \\
13 & Y13 & 0,524 & Valid \\
14 & Y14 & 0,485 & Valid \\
15 & Y15 & 0,485 & Valid \\
16 & Y16 & 0,696 & Valid \\
17 & Y17 & 0,715 & Valid \\
18 & Y18 & 0,524 & Valid \\
\hline
\end{tabular}

Berdasarkan tabel 4 diketahui bahwa seluruh indikator dalam variabel kinerja memiliki koefisien korelasi yang lebih besar dari 0,30. Jadi dapat disimpulkan bahwa seluruh indikator telah memenuhi syarat validitas data.

Dari ke 3 tabel diatas dapat diambil kesimpulan bahwa semua instrumen penelitian yang digunakan untuk mengukur variabel pengaruh kualitas sumber daya manusia dan efektifitas penggunaan sistem informasi pengaduan potensi pajak (SIDUPA) pada kinerja pegawai di kabupaten badung adalah valid karena memiliki nilai koefisien korelasi $(\mathrm{r})>0,30$.

\subsection{Hasil Uji Reliabilitas}

Reliabilitas adalah alat untuk mengukur suatu kuesioner yang merupakan indikator dari variabel atau konstruk. Suatu kuesioner dikatakan reliabel atau handal jika jawaban seseorang terhadap pernyataan adalah konsisten atau stabil dari waktu ke waktu. Uji Reliabilitas terhadap instrumen penelitian ini menggunakan nilai Cronbach Alpha, yakni untuk mengetahui unidimensionalitas butir-butir pernyataan terhadap variabel laten yang diteliti (kualitas sumber daya manusia, efektifitas penggunaan sistem 
informasi dan kinerja pegawai) Nilai Cronbach Alpha dinyatakan reliabel jika nilainya lebih besar atau sama dengan 0,60. Rekapitulasi uji reliabilitas instrumen penelitian dapat dilihat pada Tabel 5.

Tabel 5 Hasil Uji Reliabilitas

\begin{tabular}{|c|c|c|c|}
\hline No & Variabel & $\begin{array}{c}\text { Nilai Alpha } \\
\text { Cronbach }\end{array}$ & Keterangan \\
\hline 1 & $\begin{array}{l}\text { Kualitas sumber daya } \\
\text { manusia }\end{array}$ & 0,984 & Reliabel \\
\hline 2 & $\begin{array}{l}\text { Efektifitas penggunaan } \\
\text { sistem informasi } \\
\text { pengaduan potensi pajak }\end{array}$ & 0,941 & Reliabel \\
\hline 4 & Kinerja Pegawai & 0,899 & Reliabel \\
\hline
\end{tabular}

Dari tabel 5 diatas dapat dilihat nilai Cronbach Alpha untuk variabel kualitas sumber daya manusia adalah sebesar 0,984 lalu untuk variabel efektifitas penggunaan sistem informasi pengaduan potensi pajak adalah sebesar 0,941 dan untuk variabel kinerja pegawai adalah 0,899 dan ketiga variabel tersebut dinyatakan reliabel dikarenakan nilainya lebih besar dari 0,60 Sehingga dapat disimpulkan bahwa semua variabel telah memenuhi syarat reliabilitas data.

\subsection{Uji Asumsi Klasik}

Model regresi berganda akan lebih tepat digunakan dan menghasilkan perhitungan yang lebih akurat, apabila beberapa asumsi berikut dapat terpenuhi:

1. Pengujian gejala normalitas

Tabel 6. Uji Normalitas

One-Sample Kolmogorov-Smirnov Test

\begin{tabular}{|ll|r|}
\hline & & $\begin{array}{r}\text { Unstandardiz } \\
\text { ed Residual }\end{array}$ \\
\hline $\mathrm{N}$ & & 42 \\
Normal Parameters & a,b & Mean \\
Most Extreme & Std. Deviation &, 0000000 \\
Differences & Absolute & 2,65549921 \\
& Positive &, 152 \\
Kolmogorov-Smirnov Z & Negative &, 152 \\
Asymp. Sig. (2-tailed) & &,- 131 \\
\hline
\end{tabular}

a. Test distribution is Normal.

b. Calculated from data.

Berdasarkan output SPSS diperoleh nilai Asymp. Sig. (2-tailed) 0,285 yang lebih besar dari 0,05.

Hal itu berarti residual data berdistribusi normal.

2. Pengujian Gejala Heteroskedastisitas

Uji heteroskedastisitas dalam penelitian ini dilakukan dengan uji glejser. Model regresi tidak mengandung adanya heteroskedastisitas bila nilai signifikansi variabel bebasnya terhadap nilai absolut residual statistik diatas $\alpha=0,05$. Hasil uji heteroskedastisitas dapat dilihat pada Tabel 7 yaitu sebagai berikut: 
Tabel 7. Hasil Uji Heteroskedastisitas

\begin{tabular}{|c|c|c|c|c|c|c|}
\hline \multicolumn{7}{|c|}{ Coefficients } \\
\hline \multirow{2}{*}{\multicolumn{2}{|c|}{ Model }} & \multicolumn{2}{|c|}{$\begin{array}{l}\text { Unstandardized } \\
\text { Coefficients }\end{array}$} & \multirow{2}{*}{$\begin{array}{c}\begin{array}{c}\text { Standardized } \\
\text { Coefficients }\end{array} \\
\text { Beta }\end{array}$} & \multirow[b]{2}{*}{$t$} & \multirow[b]{2}{*}{ Sig. } \\
\hline & & B & Std. Error & & & \\
\hline \multirow[t]{3}{*}{1} & (Constant) & 2,301 & 1,580 & & 1,456 &, 153 \\
\hline & $\mathrm{X} 1$ & ,052 &, 047 & , 173 & 1,112 & ,273 \\
\hline & X2 &,- 034 &, 028 &,- 190 & $-1,221$ & ,229 \\
\hline
\end{tabular}

a. Dependent Variable: Abres

Berdasarkan hasil pengujian yang ditunjukkan pada tabel 7 tersebut dapat dilihat bahwa nilai signifikansi dari kualitas sumber daya manusia sebesar 0,273, dan efektivitas penggunaan sistem informasi pengaduan potensi pajak sebesar 0,229 dengan demikian dapat disimpulkan bahwa model regresi tidak mengandung adanya heteroskedastisitas.

3. Pengujian gejala multikolinearitas

Metode untuk mengetahui adanya multikolinearitas dalam model regresi adalah terlihat dari nilai tolerance dan variance inflation factor (VIF). Pada tabel di bawah ini disajikan hasil perhitungan nilai tolerance dan VIF kurang dari angka 10 dan angka tolerance lebih dari 0,1 menggunakan program SPSS.

Tabel 8. Hasil Uji Multikolinearitas

Coefficients

\begin{tabular}{|ll|r|r|}
\hline \multirow{2}{*}{ Model } & \multicolumn{2}{c|}{ Collinearity Statistics } \\
\cline { 3 - 4 } & & Tolerance & \multicolumn{1}{c|}{ VIF } \\
\hline 1 & $\times 1$ &, 995 & 1,005 \\
& $\times 2$ &, 995 & 1,005 \\
\hline
\end{tabular}

a. Dependent Variable: $Y$

Tabel 8 menunjukkan bahwa nilai tolerance sebesar 0,985 dan variance inflation factor (VIF) sebesar 1,005 sehingga variabel bebas bernilai tolerance lebih dari 0,1 atau variance inflation factor (VIF) kurang dari 10, maka disimpulkan bahwa tidak ada multikolinearitas antara variabel bebas dalam model regresi.

\subsection{Hasil Analisis Data}

1. Analisis Regresi Linear Berganda

Analisis ini digunakan untuk mengetahui pengaruh kualitas sumber daya manusia dan efektivitas penggunaan sistem informasi pengaduan potensi pajak terhadap kinerja. Hasil analisis dinyatakan dalam bentuk persamaan garis regresi linier berganda.

Tabel 9. Regresi Linear Berganda

\begin{tabular}{|c|c|c|c|c|c|c|}
\hline \multicolumn{7}{|c|}{ Coefficients } \\
\hline \multirow{2}{*}{\multicolumn{2}{|c|}{ Model }} & \multicolumn{2}{|c|}{$\begin{array}{l}\text { Unstandardized } \\
\text { Coefficients }\end{array}$} & \multirow{2}{*}{$\begin{array}{l}\text { Standardized } \\
\text { Coefficients } \\
\text { Beta }\end{array}$} & \multirow[b]{2}{*}{$t$} & \multirow[b]{2}{*}{ Sig. } \\
\hline & & $\mathrm{B}$ & Std. Error & & & \\
\hline \multirow[t]{3}{*}{1} & (Constant) & 36,397 & 2,822 & & 12,900 &, 000 \\
\hline & $\mathrm{X} 1$ & ,772 &, 084 & ,799 & 9,198 & , 000 \\
\hline & X2 & 121 & 049 & ,213 & 2,452 & 019 \\
\hline
\end{tabular}

a. Dependent Variable: $Y$

Berdasarkan nilai $a, b_{1}, b_{2}$, diperoleh persamaan garis regresi linier berganda antara kualitas sumber daya manusia dan efektifitas penggunaan sistem informasi pengaduan potensi pajak terhadap kinerja adalah : $\mathrm{Y}=36,397+0,772 \mathrm{X}_{1}+0,121 \mathrm{X}_{2}$, memberikan informasi bahwa:

1. $a=36,397$, artinya apabila tidak ada perhatian terhadap kualitas sumber daya manusia dan efektifitas penggunaan sistem informasi pengaduan potensi pajak(konstan) maka skor kinerja sebesar 36,397 
2. $b_{1}=0,772$, artinya apabila efektivitas penggunaan sistem informasi pengaduan potensi pajak $\left(X_{2}\right)$ dianggap konstan maka meningkatnya skor kualitas sumber daya manusia $\left(\mathrm{X}_{1}\right)$ sebesar satu satuan akan diikuti oleh meningkatnya skor kinerja (Y) sebesar 0,772.

3. $b_{2}=0,121$, artinya apabila kualitas sumber daya manusia dianggap konstan maka meningkatnya skor efektivitas penggunaan sistem informasi pengaduan potensi pajak $\left(\mathrm{X}_{2}\right)$ sebesar satu satuan akan diikuti oleh meningkatnya skor kinerja (Y) sebesar 0,121.

2. Uji F

Uji F digunakan untuk melihat bahwa pengaruh variabel bebas secara simultan terhadap variabel terika serta untuk menguji apakah model yang digunakan dalam penelitian ini layak (fit). Model dikatakan layak apabila F hitung lebih kecil dari $0,05(\alpha=5 \%)$. Jika model yang digunakan fit, hal ini memberikan makna bahwa variabel bebas dalam penelitian ini mampu memprediksi atau menjelaskan variabel terikat. Uji F merupakan uji yang menunjukkan bagaimana pengaruh semua variabel bebasnya yang secara bersama-sama terhadap variabel terikatnya.

Tabel 10 U ji Kelayakan Model (Uji F)

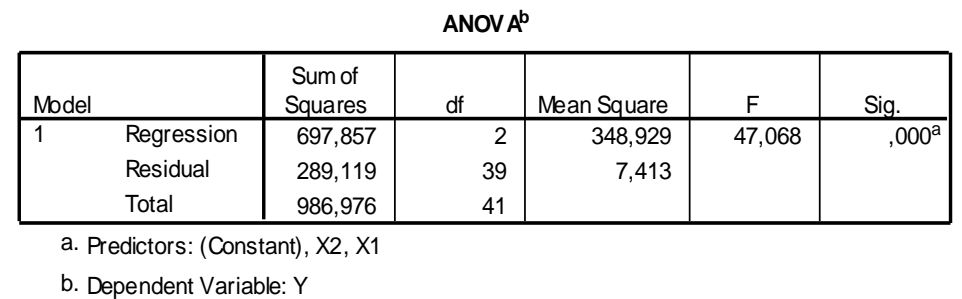

Berdasarkan Tabel 10 menunjukkan Fhitung sebesar 47,068 dan nilai signifikansi 0,000 yang lebih kecil dari 0,05 atau nilai sig 0,000 0,05 ini berarti bahwa ada pengaruh antara variabel kualitas sumber daya manusia dan efektivitas sistem informasi pengaduan potens pajak terhadap variabel kinerja.

3. Uji-t

Uji ini digunakan untuk menguji signifikansi pengaruh antara kualitas sumber daya manusia dan efektifitas penggunaan sistem informasi pengaduan potensi pajak secara parsial terhadap kinerja adalah signifikan atau hanya diperoleh secara kebetulan. Pada uji ini dapat dilakukan dengan membandingkan tingkat signifikansinya. Jika nilai signifikan lebih kecil dari alpha 0,05 menunjukkan bahwa $\mathrm{H}_{\mathrm{o}}$ ditolak dan $\mathrm{H}_{\mathrm{a}}$ diterima. Sehingga perlu menguji signifikasi masing-masing koefisien regresi, yaitu untuk :

Tabel 11 Nilai T hitung

Coefficients

\begin{tabular}{|c|c|c|c|c|c|c|}
\hline \multirow{2}{*}{\multicolumn{2}{|c|}{ Model }} & \multicolumn{2}{|c|}{$\begin{array}{l}\text { Unstandardized } \\
\text { Coefficients }\end{array}$} & \multirow{2}{*}{$\begin{array}{c}\text { Standardized } \\
\text { Coefficients } \\
\text { Beta }\end{array}$} & \multirow[b]{2}{*}{$t$} & \multirow[b]{2}{*}{ Sig. } \\
\hline & & $\mathrm{B}$ & Std. Error & & & \\
\hline & (Constant) & 36,397 & 2,822 & & 12,900 &, 000 \\
\hline & $\mathrm{X} 1$ & ,772 & ,084 & ,799 & 9,198 & ,000 \\
\hline & X2 & ,121 & ,049 & ,213 & 2,452 &, 019 \\
\hline
\end{tabular}

a. Dependent Variable: $Y$

1. Pengaruh kualitas sumber daya manusia terhadap kinerja

Hasil penelitian menunjukkan koefisien regresi sebesar 0,772 dan nilai $t_{\text {hitung }}=9.198$ sig 0,000 pada taraf signifikansi $5 \%$ berarti $\mathrm{H}_{\mathrm{O}}$ ditolak dan $\mathrm{H}_{\mathrm{a}}$ diterima. Ini berarti bahwa ada pengaruh positif dan signifikan secara parsial kualitas sumber daya manusia terhadap kinerja.

2. Pengaruh efektifitas penggunaan informasi pengaduan potensi pajak terhadap kinerja

Hasil penelitian menunjukkan koefisien regresi sebesar 0,121 dan nilai $t_{\text {hitung }}=2,452$ sig 0,019 pada taraf signifikansi $5 \%$ berarti $\mathrm{H}_{\mathrm{O}}$ ditolak dan $\mathrm{H}_{\mathrm{a}}$ diterima. Ini berarti bahwa ada pengaruh 
positif dan signifikan secara parsial efektivitas pengguaan informasi pengaduan potensi pejak terhadap kinerja.

4. Analisis Determinasi

Untuk mengetahui besarnya pengaruh antara kualitas sumber daya manusia $\left(\mathrm{X}_{1}\right)$ dan efektivitas penggunaan sistem informasi pengaduan potensi pajak $\left(\mathrm{X}_{2}\right)$ terhadap kinerja karyawan, maka digunakan analisis determinasi berganda. Pada rekapitulasi hasil SPSS pada Tabel 12

Tabel 12 Koefisien Determinasi

Mode I Sum marb

\begin{tabular}{|l|r|r|r|r|}
\hline Model & $\mathrm{R}$ & $\mathrm{R}$ Square & $\begin{array}{c}\text { Adjusted } \\
\text { R Square }\end{array}$ & $\begin{array}{c}\text { Std. Error of } \\
\text { the Estimate }\end{array}$ \\
\hline 1 &, $841^{\mathrm{a}}$ &, 707 &, 692 & 2,72274 \\
\hline
\end{tabular}

a. Predictors: (Constant), $\times 2, \times 1$

b. Dependent $V$ ariable: $Y$

Besarnya determinasai $\left(\mathrm{R}^{2}=0,707\right)$ ini berarti pengaruh kualitas sumber daya manusia dan efektivitas sistem informasi pengaduan potensi pajak terhadap kinerja sebesar 70,7\% sedangkan sisanya sebesar $29,3 \%$ dipengaruhi oleh faktor lain diluar penelitian ini.

5. Analisis Deskriptif

Data yang telah terkumpul baik kualitatif maupun kuantitatif selanjutnya dianalisis secara deskriptif.

Data angket yang bersifat ordinal dianalisis menggunakan three box method,

Tabel 13 Statistik Deskriptif

\begin{tabular}{|l|r|r|r|r|r|}
\hline \multicolumn{7}{|c|}{ De scriptive Statistics } \\
\hline X1 & N & Minimum & Maximum & \multicolumn{1}{c|}{ Mean } & Std. Deviation \\
X2 & 42 & 12,00 & 32,00 & 24,0238 & 5,07739 \\
Y & 42 & 26,00 & 64,00 & 42,0714 & 8,65995 \\
Valid N (listw ise) & 42 & 49,00 & 72,00 & 60,0238 & 4,90638 \\
\hline
\end{tabular}

Pada tabel 13 diatas dapat dilihat variabel kinerja pegawai (Y) memiliki nilai terendah sebesar 49,00 dan nilai tertinggi sebesar 72,00 dengan nilai rata-ratanya sebesar 60,038 dan standar defiasinya (tingkat selebaran datanya) sebesar 4,90638. Lalu dilakukan perhitungan menurut dengan menggunakan kriteria tiga kotak (Three-box Method) untuk menentukan kategori dari nilai indeks yang dihasilkan, yaitu rentang 49,00-56,66 (rendah), 56,67-64,33 (sedang) dan 64,34-72,00 (tinggi). Berdasarkan hasil perhitungan nilai indeks rata-rata variabel kinerja pegawai adalah sebesar 60,0238 (kategori sedang).

Selanjutnya dapat dilihat variabel kualitas sumber daya manusia (X1) memiliki nilai terendah sebesar 12,00 dan nilai tertinggi sebesar 32,00 dengan nilai rata-ratanya sebesar 24,0238 dan standar defiasinya (tingkat selebaran datanya) sebesar 5,07739. Lalu dilakukan perhitungan dengan menggunakan kriteria tiga kotak (Three-box Method) untuk menentukan kategori dari nilai indeks yang dihasilkan, yaitu rentang 12,00-18,66 (rendah), 18,67-25,33 (sedang) dan 25,34-32,00 (tinggi). Berdasarkan hasil perhitungan nilai indeks rata-rata variabel kualitas sumber daya manusia adalah sebesar 24,0238 (kategori sedang).

Terakhir variabel kinerja pegawai (X2) memiliki nilai terendah sebesar 26,00 dan nilai tertinggi sebesar 64,00 dengan nilai rata-ratanya sebesar 42,0714 dan standar defiasinya (tingkat selebaran datanya) sebesar 8,65995. Lalu dilakukan perhitungan dengan menggunakan kriteria tiga kotak (Three-box 
Method) untuk menentukan kategori dari nilai indeks yang dihasilkan, yaitu rentang 26,00-38,66 (rendah), 38,67-51,33 (sedang) dan 51,34-64,00 (tinggi). Berdasarkan hasil perhitungan nilai indeks rata-rata variabel kualitas sumber daya manusia adalah sebesar 42,0714 (kategori sedang).

\section{Kesimpulan}

5.1 Simpulan

1. Kualitas sumber daya manusia berpengaruh positif dan signifikan secara parsial terhadap kinerja pegawai di Kabupaten Badung.

3. Ada pengaruh positif dan signifikan secara parsial efektivitas pengguaan sistem informasi pengaduan potensi pejak terhadap kinerja.

4. Ada pengaruh antara variabel kualitas sumber daya manusia dan efektivitas sistem informasi pengaduan potensi pajak terhadap variabel kinerja.

5. pengaruh kualitas sumber daya manusia dan efektivitas sistem informasi pengaduan potensi pajak terhadap kinerja sebesar 70,7\% sedangkan sisanya sebesar 29,3\% dipengaruhi oleh faktor lain diluar penelitian ini.

\subsection{Saran}

1. Karena kualitas sumber daya manusia berpengaruh terhadap kinerja pegawai maka diharapkan Pemerintah Kabupaten Badung bisa terus mempertahankan kinerja pegawainya dengan cara memberikan kesempatan untuk mengikuti pelatihan-pelatihan yang terkait dengan pekerjaan yang akan mereka lakukan agar didalam penyelesaian setiap tugas atau pekerjaan dapat diselesaikan sesuai dengan prosedur yang ditetapkan oleh Pemerintah Kabupaten Badung.

2. Karena adanya pengaruh antara sistem informasi pengaduan potensi pejak terhadap kinerja pegawai maka diharapkan Pemerintah Kabupaten Badung agar lebih memperhatikan sistem tersebut atau lebih dikembangkan lagi sehingga dikemudian hari sistem tersebut bisa di gunakan lebih mudah dan agar dapat mengurangi tingkat error dalam penggunaannya. Selain itu diharapkan Pemerintah Kabupaten Badung juga memberikan pelatihan kepada pegawai agar bisa lebih memahami pentingnya sistem informasi pengaduan potensi pajak untuk meningkatkan kinerja pegawai.

3. Untuk penelitian selanjutnya, disarankan untuk memperluas cakupan penelitiannya. Baik dari segi jenis respondennya, dari cakupan wilayah kerjanya, bahkan jenis variabelnya. Karena sistem informasi pengaduan potensi pajak masih akan dikembangkan lagi maka diharapkan penelitian selanjutnya bisa lebih berkembang dan bisa lebih akurat hasil penelitiannya untuk bisa mendukung penelitian sebelumnya.

\section{Daftar Rujukan}

[1] Sinambela, Lijan Poltak. 2016. Manajemen Sumber Daya Manusia. Jakarta: PT Bumi Aksara

[2] Mathis, Robert L. dan John H. Jackson. 2012. Manajemen Sumber Daya Manusia, Edisi Pertama Salemba Empat, Jakarta

[3] Vemon, M. (2011). BISNIS: The Key Concepts. Jakarta: Rajawali Pers.

[4] Republik Indonesia, Peraturan Pemerintah No. 24 Tahun 2005 tentang Standar Akuntasi Pemerintahan

[5] Abdul Halim dkk, 2012. Akuntansi Sektor Publik Akuntansi Keuangan Daerah. Edisi 4. Penerbit Salemba Empat. Jakarta.

[6] Republik Indonesia, Peraturan Menteri Dalam Negeri Nomor 13 Tahun 2006 Tentang Pedoman Pengelolaan Keuangan Daerah

[7] Ardana,I Cenik; Lukman,Hendro. 2016. Sistem Informasi Akuntansi. Jakarta:Mitra. Wacana Media.

[8] A.A. Anwar Prabu Mangkunegara. 2009. Manajemen Sumber Daya Manusia. Bandung: PT. Remaja Rosdakarya

[9] Sinambela, Lijan Poltak. 2016. Manajemen Sumber Daya Manusia. Jakarta: PT Bumi Aksara

[10] Sugiyono. (2013). Metode Penelitian Kuantitatif, Kualitatif dan R\&D. Bandung: Alfabeta.

[11] Priyatno, Duwi (2014). SPSS 22 Pengolah Data Terpraktis. Yogyakarta: Andi

https://doi.org/10.33998/mediasisfo.2019.13.1.599 
[12] Sarjono, H., \& Julianita, W. (2011). SPSS vs LISREL: Sebuah Pengantar, Aplikasi untuk Riset. Jakarta: Salemba Empat.

[13] Gujarati, Damodar. 2003. Ekonometrika Dasar. Terjemah Sumarno Zein. Jakarta: Erlangga.

[14] Santoso, S. 2000. Statistik Parametrik. Jakarta : PT. Elex Komputindo. 